\title{
Managing Shared Basins in the Horn of Africa - Ethiopian Projects on the Juba and Shabelle Rivers and Downstream Effects in Somalia
}

\author{
Abdullahi Elmi Mohamed \\ Department of Land and Water Resources Engineering, Royal Institute of Technology, Teknikringen 76, SE 10044 Stockholm, Sweden \\ *Corresponding Author: elmi@kth.se
}

Copyright (C) 2013 Horizon Research Publishing All rights reserved.

\begin{abstract}
The Juba and Shabelle Rivers in the Horn of Africa are shared by Ethiopia, Kenya and Somalia. Most of the rivers' runoff originates from Ethiopia. Being in a water-scarce and war-ravaged region, the rivers cross areas of border dispute. The paper examines the physical and developmental aspects of the rivers, and analyses resulting trans-boundary river management issues. Methodology used is document reviews, literature analysis and interviews. The rivers supply important economic areas in Somalia. As an outcome from the master plan studies of the basins, Ethiopia is implementing large dams for hydropower generation and large irrigation schemes. No agreements exist between the basin countries. These unilateral major water development projects will have substantial adverse impacts on Somalia. The sum of existing water uses and planned demands in both countries will exceed available water resources in the rivers. Potential disputes over the shared rivers are therefore likely to rise. Turning this risk of conflict into a sustainable peace and development process in the region, the paper presents and analyses existing \& potential opportunities for cooperation over the rivers for mutual benefit sharing. Broader regional economic integration through river cooperation seems to be the only and necessary solution for the looming crisis.
\end{abstract}

Keywords Conflict, Ethiopia, Juba And Shabelle, Kenya River Cooperation, Shared Rivers, Somalia, Water Projects

\section{Introduction}

Rivers are the most important sources of freshwater and play a major role in society's economic development and in maintaining life supporting ecosystems services. In general terms water resources management becomes increasingly critical and as new local and national sources of water become scarce, limited, expensive and difficult to exploit [1], many countries in the arid and semi-arid regions that are facing water crisis [2, 3] will be increasingly forced to consider the possibilities of utilizing the water that is available in international river basins [4]. Thus, the concerns relating to the use of international waters are becoming increasingly more important and complex. Because most remaining major easily exploitable sources of freshwater are now in river basins that are shared by two or more sovereign States $[2,5]$. Shared rivers in dry climate regions could be a source of conflict or a reason for cooperation between countries sharing them. Although potential for water-based conflict is real in Africa $[6,7,8]$ and apparent in arid climate [9], in several cases, the competing and disputing riparian countries are now moving towards cooperation [10]. In Africa, most water resources are transboundary and 63 transboundary river basins account $85 \%$ of the freshwater resources [7]. In terms of land area within international basins, Africa has the greatest percentage of all, $62 \%$ [11]. These basins present special difficulties. It is projected that by 2025 half of African countries will experience water stress and the sharing of water will play a significant role in inter-state relations amidst a combination of population growth and recurrent drought and famine in some parts of the continent $[12,13]$. Considering transboundary water resources as a common-pool resources and regional public goods, providing incentives for cooperation and integration of interests between riparian countries is necessary [14].

The Horn of Africa is a water scarce region which is vulnerable to hydrological variations. The Horn of African countries have already joined to the list of countries that are facing water scarcity [12, 15]. Region's available water resources exist in rivers shared by neighbouring countries. Two issues that are increasing affecting domestic policy options are population growth and food security. These will in turn affect the available water in the shared rivers.

The Juba and Shabelle rivers in the Horn of Africa are shared by Ethiopia, Kenya and Somalia, see Figure 1. The region's primary economy is agriculture and there is a desperate need to increase water uses for food and 
hydropower production. Riparian countries have never discussed cooperation over these rivers [16]. The region has also been ravaged by civil wars.

\subsection{Purpose and objectives}

The overall purpose of the paper is to analyse the management of the international freshwater resources with focus on the Juba and Shabelle Rivers in the Horn of Africa and to analyse the resulting transboundary water management issues. As these rivers have not been studied before from any transboundary perspective, the paper may lead towards a realization of how an effective management of these international river basins could be planned in the future. The specific objectives of the paper are to study and analyse following questions:

1. How to transform the current situation of zero-sum game into plus-sum one through sharing benefits in mutual interest from the common water resources in the rivers?

2. What are the existing and planned uses of the rivers' water resources and how these uses will impact on the overall management and sharing of the resources?

3. How important are these rivers, the Juba and Shabelle, for the countries sharing them and what are currently the major obstacles for establishing required river cooperation?

4. How will the Ethiopian major planned water projects affect downstream uses in Somalia?

5. Why was it difficult or impossible in the past to create a collaborative climate between the riparian countries? Are there any risks for interstate conflict based on water in the rivers?

6. Why is it necessary to seek for cooperation over the Juba and Shabelle river basins?

7. Demonstrating the necessity of river cooperation, what will be the driving forces for the required future cooperation over the river systems?

\section{Material and methods}

The research design selected for this paper is a qualitative case study analysis. Being a research design that entails the detailed and intensive analysis of a single case [19], case study research is concerned with the complexity and particular nature of the case in question [17]. Yin points out that case study are the preferred strategy when "how" and "why" questions are posed [18]. Data and information were mainly collected from official documents. Methods applied for the paper study include document and literature review, text analysis, interviews with key and professional persons during study visits. Information collected include regional situation on water resources, physical and hydrological aspects of the selected shared rivers, existing and planned water projects and other documents about international waters. Documents that are collected, reviewed, analysed and examined include also the master plan studies of the Juba and Shabelle rivers by both Ethiopia and Somalia. The riparian countries' policies towards development of the rivers have also been studied and analysed. Analysing the extent to which these rivers' water resources are utilized and plans to further develop them, different and competing riparian countries' needs and arguments were matched with the existing internationally accepted water principles.

Several study visits were paid to the region with the aim of collecting data, meeting with water institutions and interviewing relevant people who directly involve in these rivers' management.

\section{Physical geography of the river basins}
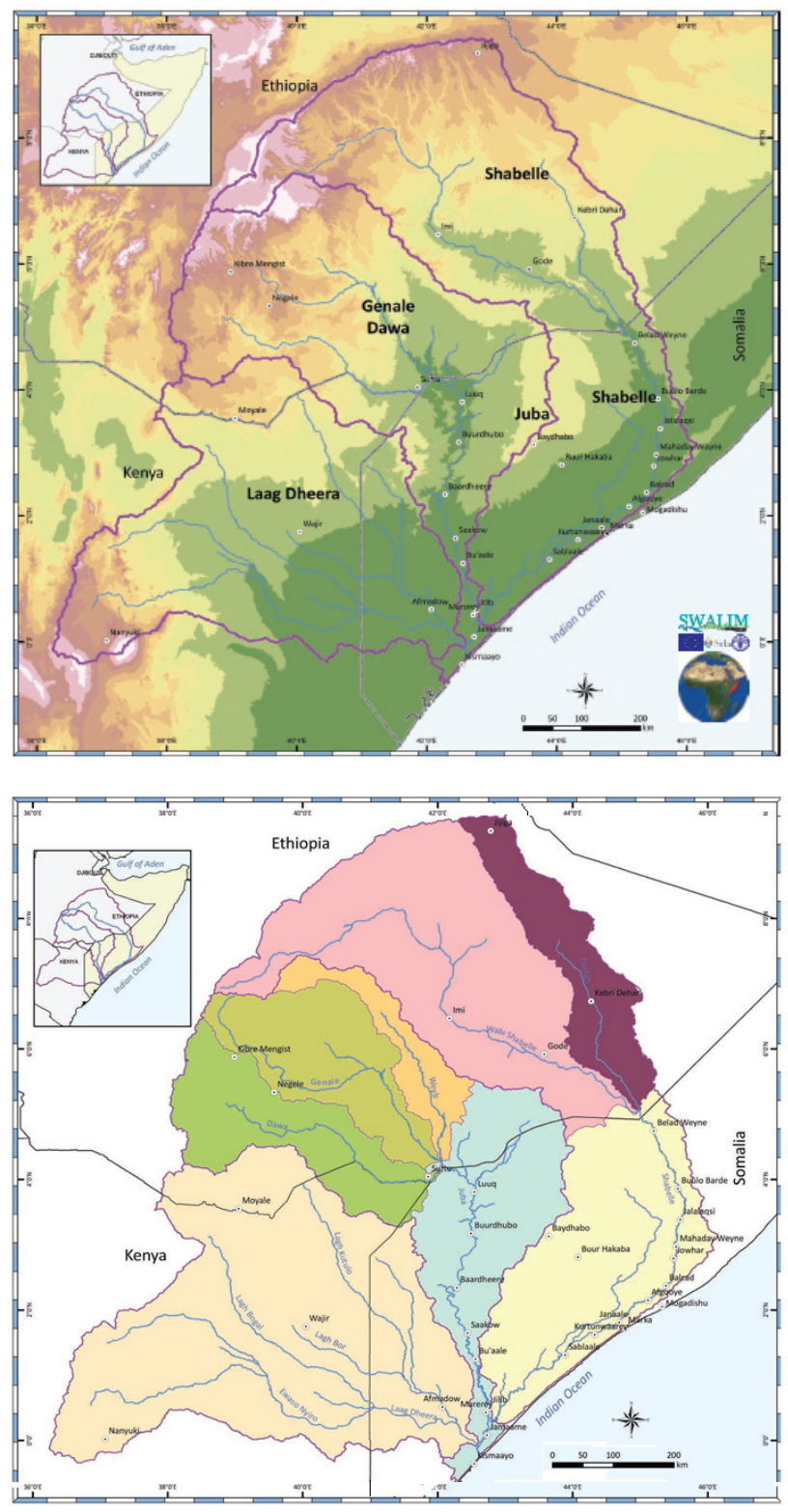

Figure 1. Map of the Juba and Shabelle basins [20]. 


\subsection{The Shabelle River Basin}

Originating from the Bale Mountain in the Ethiopian highlands, at an altitude of about $4230 \mathrm{~m}$ above sea level, the total catchment area of the Shabelle river basin (see Figure 1) is $297000 \mathrm{~km}^{2}$ [20]. Nearly two-third (63.5\%) of the basin area lies in Ethiopia and one-third in Somalia [ibid.]. Within Ethiopia, the river has several tributaries contributing to its runoff. Flowing generally south-easterly direction; the Shabelle River passes through an arid land in the eastern province of Ethiopia cutting wide valleys in southern Somalia. Running a distance of about $2526 \mathrm{~km}$, of which 1 $290 \mathrm{~km}$ in Ethiopia, the river does not normally enter the Indian Ocean, but into a depression area, where it is finally lost in the sand in southern Somalia, feeding an ecologically sensitive area and recharging areas of groundwater aquifers. Only with exceptionally heavy rains does the Shabelle River break through to join the Juba River and thus succeed in reaching the Indian Ocean.

With an average annual rainfall of $425 \mathrm{~mm}$ (over 1500 $\mathrm{mm}$ in the mountain areas and $200 \mathrm{~mm}$ near the border), mean annual runoff of the river at the town of Gode in Ethiopia is $3387 \mathrm{Mm}^{3}$ [21], and at the town of Belet-Weyne in Somalia is $2384 \mathrm{Mm}^{3}$ [22]. About $1,000 \mathrm{Mm}^{3}$ is lost in the Ogaden desert in eastern Ethiopia. The river runoff is totally generated by catchments within Ethiopia [21, 22]. The river has a high saline content even during high flows. Figure 2 shows the two rivers' long term flows near the Somali and Ethiopian border.

Due to its climate conditions, the basin is frequently affected by droughts and floods causing major problems to mainly downstream communities in Somalia.

The basin contains also other unexploited but discovered natural resources such as minerals, petroleum and natural gas. It also has a large number of livestock.

\subsection{The Juba River Basin}

Like the Shabelle, the Juba River originates from the Ethiopian Highlands, where three large tributaries, the Genale, the Dawa and the Weyb (Gestro), meet near the border with Somalia to form what is known the Juba River inside Somalia. The Dawa river forms part of Ethiopia-Kenya border. Along its final reach, the Dawa tributary marks also the Ethiopia-Somalia border. The Juba has a basin area of $452000 \mathrm{~km}^{2}$ [21]. The basin includes also the Laag Dheera sub-basin which is mostly in Kenyan territory, see Figure 1. The Laar Dheera sub-basin contains several tributaries joining in Somalia. These include the Ewaso Nyiro tributary originating from Mount Kenya, at an altitude of about $5195 \mathrm{~m}$ a.s.l. Within the sub-basin, there is a large transboundary aquifer, the Merti, stretching over the Kenya-Somalia border. The Merti aquifer contains large amount of unexploited groundwater of about $84000 \mathrm{Mm}^{3}$ [23]. The Juba, which enters the Indian Ocean at Kismayo town in southern Somalia, has a total length of $1808 \mathrm{~km}$, of which $840 \mathrm{~km}$ lies in Ethiopia and $1004 \mathrm{~km}$ in Somalia [20].

Rainfall at the source reaches $1600 \mathrm{~mm} / \mathrm{y}$, dramatically decreasing southwards, where the mean reduces to 200 $\mathrm{mm} / \mathrm{y}$ in the areas near the border. The average annual rainfall of the entire basin is about $500 \mathrm{~mm}$. The mean annual runoff of the river in Ethiopia is $6600 \mathrm{Mm}^{3}$ [24] and 6200 $\mathrm{Mm}^{3}$ in Somalia [25]. Ethiopia again contributes over $95 \%$ $[22,24,25]$. The Laag Dheera sub-basin, which is mainly in Kenya, is very arid and has no significant surface runoff contributions to the river system. It seems that the runoff from the sub-basin recharges the Merti aquifer. The Juba River transports substantial volumes of sediment [24].

As Figure 2 shows the long term mean flows of the rivers, the amount of the water flowing in the rivers vary greatly within the year. The average flow of the Juba at Luuq is 200 $\mathrm{m}^{3} / \mathrm{s}$ while the Shabelle has an average flow of $75 \mathrm{~m}^{3} / \mathrm{s}$ at Beled-Weyne in Somalia. The Juba has an annual runoff which is almost three times higher than the Shabelle in Somalia.

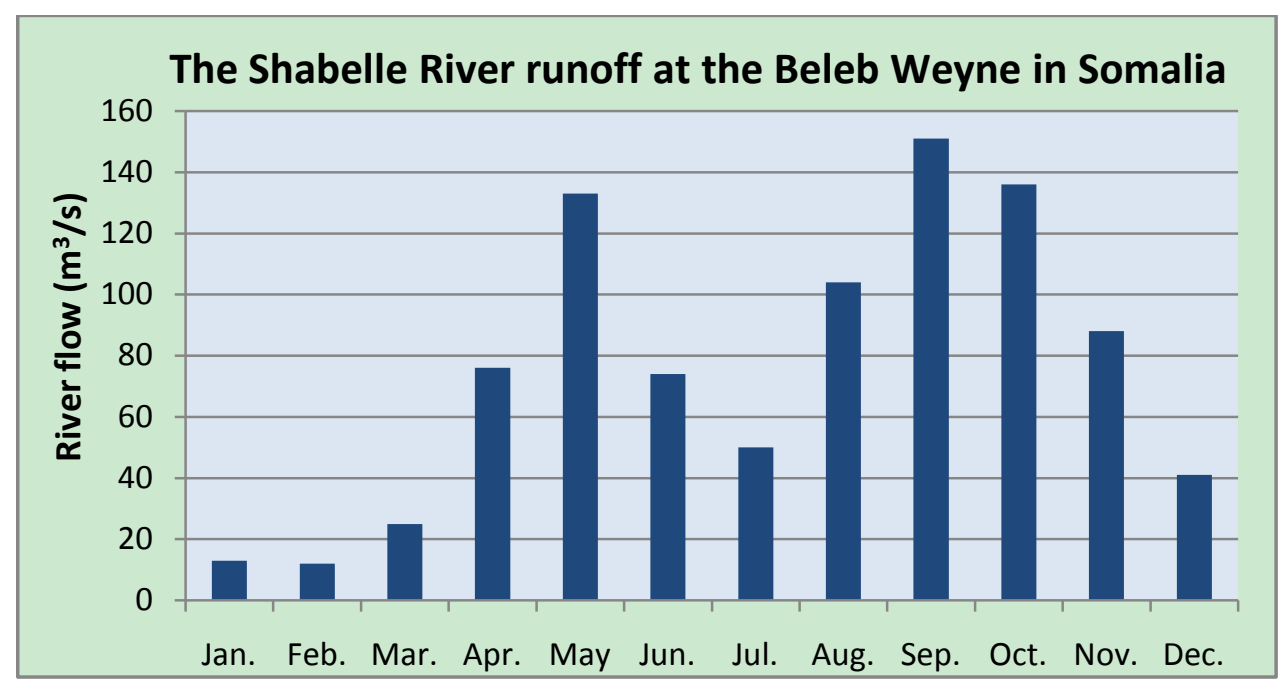

Figure 2. Long term mean flow for the Juba and Shabelle rivers in Somalia [22]. 
The two river basins could be considered as one basin with three sub-basins - the Shabelle, the Juba and the Laag Dheera. In total, they occupy a land area of $749000 \mathrm{~km}^{2}$ [20]. The total drainage area of the two basins was also previously estimated to $805100 \mathrm{~km}^{2}$ [11]. The rivers generate small amount of runoffs due to the high evapotranspiration and low rainfall. As Somalia's most water resources exist in these rivers, runoff contributions by catchments in Somalia are normally minimal. The effects of this factor will be analyzed later in the paper.

The total population in the two basins is estimated to 30 million and the annual population growth rate is over $3 \%[20$, $24,25]$.

\section{River Developments and Economic Water Uses}

\subsection{Existing water uses in the Juba \& Shabelle basins}

\subsubsection{Ethiopia}

In upstream areas of Ethiopia, there are currently two major water projects. Melka Wakana hydropower dam with discharge release of $60 \mathrm{~m}^{3} / \mathrm{s}$ was commissioned in 1988 to produce $153 \mathrm{MW}$ [21]. The dam, with storage capacity of $763 \mathrm{Mm}^{3}$ [26] is the only one existing in the basin. The released water is intended to use for irrigation near the town of Gode. Gode irrigation project with a $17 \mathrm{~km}$ long canal has the capacity to irrigate 17000 ha of land [21]. The canal, with a discharge capacity of $46 \mathrm{~m}^{3} / \mathrm{s}$, consumes large amount of water in the semi-desert area of Ogaden in eastern Ethiopia greatly reducing downstream flows to Somalia by over $60 \%$.

There are no currently significant water uses in the Genale-Dawa River Basin in Ethiopia. At the present time, no storage reservoir for hydropower generation or other purposes have been constructed. Agricultural economy is predominantly based on small scale rain-fed subsidence farming and small-scale irrigation schemes for cash crop production. In the highlands, livelihoods are crop production while in the lowlands area where rainfall is inadequate; livelihoods are primarily dependent on livestock production.

\subsubsection{Kenya}

The Kenyan side of the basin is very dry and there are no major water uses. Along the Dawa river, there is a small irrigation scheme in Rhamu, Mandera area which is partly flood-plain irrigation and partly groundwater-irrigated [27]. Kenyan water uses in the basin concentrates mainly on the groundwater uses in the Merti aquifer for small scale domestic water supplies.

\subsubsection{Somalia}

As the two rivers supply the Somalia's rice bowl and support important economic areas in southern Somalia, several agricultural development projects based on the water resources of the two rivers have been implemented from independence in 1960 until state collapse in 1991.

Table 1. Barrages for flow control of the Shabelle and Juba Rivers in Somalia before the civil war in 1991.

\begin{tabular}{|c|c|c|}
\hline Irrigation Scheme (barrage*) & $\begin{array}{c}\text { Command } \\
\text { areas (ha) }\end{array}$ & $\begin{array}{c}\text { Purpose and year of } \\
\text { construction }\end{array}$ \\
\hline Saabuun barrage & 50942 & Irrigation 1970 \\
\hline Balcad barrage & 10000 & Irrigation 1967 \\
\hline Janaale barrage & 67440 & Irrigation 1927 \\
\hline Mashalaay barrage & 27000 & Irrigation 1986 \\
\hline Qoryooley barrage & 4120 & Irrigation 1955 \\
\hline Falkeerow barrage & 26800 & Irrigation 1955 \\
\hline Kurtunwaarey barrage & 5000 & Irrigation 1986 \\
\hline Sablaale barrage & 940 & Irrigation 1970 \\
\hline Hawaay barrage & 3000 & Irrigation 1970 \\
\hline Fanole barrage & 15250 & Irrigation 1970 \\
\hline TOTAL & 210942 & \\
\hline
\end{tabular}

Source: $[28,29] . *$ A type of dam with dam with a line of gates that can be opened or closed to control the amount of water flow.

Before the outbreak of the civil war in 1991, ten barrages (nine in the Shabelle and one in the Juba) and one dam for regulation of the rivers with irrigation canals were built to put 222950 hectares of land under irrigation [28], see Table 1 and 2. Inside Somalia, no dam was built on the Shabelle River, but there are many major agricultural developments along the river that intensively use much of the available water. Off-stream facility with storage capacity of $200 \mathrm{Mm}^{3}$ was also built in 1980 near the town of Jowhar for river flow regulation for downstream irrigation uses [29]. A flood relied canal and reservoir (Chinese/Duduble canal) was also built in 1983 upstream of Jowhar town for reducing risk of flooding and for conveying the floodwaters to other areas for irrigation.

Based on these existing irrigation schemes in the Shabelle basin in Somalia, large amount of the river's available water resources is consumed for agricultural production in Somalia.

These existing irrigation schemes in the Juba basin in Somalia, before the civil war, demanded an amount of water of $2838 \mathrm{Mm}^{3}$ [25]. The Fanole dam project, the only dam existing in Somalia constructed in 1977 in the Juba River near the town of Jilib, has a multipurpose development for irrigation, hydropower and flood mitigation. As a result of the civil war, all the ten barrages, the Fanole dam and related canals are currently not operational and require major 
rehabilitation work [30].

Table 2. Irrigation schemes on the Juba river in Somalia before the civil war in 1991.

\begin{tabular}{|c|c|c|}
\hline Irrigation Scheme (barrage) & $\begin{array}{c}\text { Command } \\
\text { areas (ha) }\end{array}$ & $\begin{array}{c}\text { Purpose and year } \\
\text { of construction }\end{array}$ \\
\hline Juba Sugar Project & 7000 & Irrigation 1980 \\
\hline Fanole irrigation System & 15250 & Irrigation 1977 \\
\hline Mogambo Irrigation Proj. & 2200 & Irrigation 1986 \\
\hline Medium/Small-scale schemes & 3400 & Irrigation 1984 \\
\hline TOTAL & 27850 & Irrigation \\
\hline
\end{tabular}

Source: [25, 28, 29, 35].

Somalia uses the Shabelle waters more than the Juba. This could be attributed to the topography of the Shabelle River and the land in which it passes through which is wider and larger than that of the Juba. The Shabelle is longer than Juba and closer to the capital. Moreover, in the Juba basin with its deep valleys, one has to pump the water for irrigation. This is the case of the Mogambo irrigation project in the Juba, when the water gate for the canal does not reach the river intake point as a result of lower water level, forcing the use of the pumping project. Despite of these limitations, the Juba has potential resources for economic development.

\subsection{Planned water uses in the Juba \& Shabelle basins}

\subsubsection{Ethiopia}

According to the Wabi Shabelle River Basin Integrated Development Master Plan Study Project [21], 141 irrigation schemes (25 large, 76 medium and 40 small irrigation projects) with net irrigable area of 209310 ha were identified for irrigation development consuming an amount of water estimated to $2566 \mathrm{Mm}^{3}$ available in Ethiopia, which is much more than what is available at the border with Somalia (2 $384 \mathrm{Mm}^{3}$ ). In a three phases irrigation development plans from 2005 to 2035, the first phase will irrigate 26705 ha of land, the second phase 53339 ha, and the third phase 109950 ha. The master plan, finalized in 2005, has also identified 21 potential hydropower sites. After screening, six large dams together generating $1000 \mathrm{MW}$ and having combined storage capacities of over $10000 \mathrm{Mm}^{3}$ were selected for their capacity of water exploitation [31]. The master plan includes also water supply projects for increasing and urbanized population of 15 million in the Ethiopian part of the basin. Table 3 shows some of the immediate water projects proposed to be implemented during the period between 2005 and 2015.
Table 3. Some of the immediate projects on the Shabelle in Ethiopia.

\begin{tabular}{|c|c|c|c|}
\hline Dam Project & $\begin{array}{c}\text { Height } \\
(\mathrm{m})\end{array}$ & $\begin{array}{c}\text { Storage } \\
\text { capacity } \\
\left(\mathrm{Mm}^{3}\right)\end{array}$ & Development purpose \\
\hline Dam WS18 & 120 & 3681 & $\begin{array}{c}\text { Irrigation (120 000 ha) } \\
\text { hydropower } \\
117 \text { MW, flood } \\
\text { mitigation, water supply }\end{array}$ \\
\hline $\begin{array}{c}\text { Dam WS9 } \\
\text { Inter basin } \\
\text { transfer }\end{array}$ & 105 & 715 & $\begin{array}{c}\text { Multipurpose dam - } \\
\text { irrigation, hydropower } \\
60 \text { MW. }\end{array}$ \\
\hline \hline $\begin{array}{c}\text { Irrigation Project } \\
\text { (ha) }\end{array}$ & Region & $\begin{array}{c}\text { Related infrastructures } \\
\text { Hydropower } 80 \mathrm{MW} .\end{array}$ \\
\hline $\begin{array}{c}\text { Erer irrigation } \\
\text { Project }\end{array}$ & 3000 & Harari & $\begin{array}{c}30 \text { m high dam, 23 km } \\
\text { long canals. }\end{array}$ \\
\hline $\begin{array}{c}\text { Gololcha } \\
\text { irrigation Project }\end{array}$ & 8920 & Oromiya & $\begin{array}{c}58 \text { m high dam, } 39 \mathrm{~km} \\
\text { long canals. }\end{array}$ \\
\hline
\end{tabular}

Source: [21].

Table 4. Some of the immediate water projects on the Genale-Dawa River in Ethiopia

\begin{tabular}{|c|c|c|c|}
\hline Dam Project & $\begin{array}{l}\text { Height } \\
(\mathrm{m})\end{array}$ & $\begin{array}{l}\text { Storage } \\
\text { capacity } \\
\left(\mathrm{Mm}^{3}\right)\end{array}$ & Purpose \\
\hline $\begin{array}{l}\text { Dam } \\
\text { GD-03 } \\
\text { full river } \\
\text { regulation }\end{array}$ & 105 & 2900 & $\begin{array}{l}\text { Irrigation, hydropower } 265 \\
\text { MW, river regulation, } \\
\text { flood control, fishery, } \\
\text { tourism, urban water } \\
\text { supply. }\end{array}$ \\
\hline Dam GD-06 & 50 & 3000 & $\begin{array}{l}\text { Hydropower generation, } \\
200 \mathrm{MW} \text {. }\end{array}$ \\
\hline $\begin{array}{c}\text { Dam } \\
\text { GD-02 }\end{array}$ & 130 & 1046 & $\begin{array}{c}\text { Irrigation, hydropower } 130 \\
\text { MW, river regulation, } \\
\text { flood control, fishery, } \\
\text { tourism. }\end{array}$ \\
\hline Dam GD-05 & 35 & 3000 & $\begin{array}{l}\text { Multipurpose dam, } \\
\text { hydropower } 106 \mathrm{MW} \text {. }\end{array}$ \\
\hline $\begin{array}{l}\text { Dam GD-07 } \\
\text { full river } \\
\text { regulation }\end{array}$ & 50 & - & $\begin{array}{c}\text { Hydropower generation, } \\
185 \mathrm{MW} .\end{array}$ \\
\hline Dam GD-08 & 50 & - & $\begin{array}{l}\text { Hydropower generation, } \\
82 \mathrm{MW} \text {. }\end{array}$ \\
\hline $\begin{array}{l}\text { Inter basin } \\
\text { transfer }\end{array}$ & 29 & 120 & Hydropower $80 \mathrm{MW}$. \\
\hline
\end{tabular}

Source: [31].

According to the Genale-Dawa River Basin Master Plan Study of Ethiopia [32a], 93 medium and large scale schemes with over a million hectares of potential irrigable land areas were proposed for irrigation consuming a large amount of water available in the basin. After a further study, they were reduced to 10 candidate projects of irrigation. The master 
plan, which was finalized and presented in 2007, identified 22 dam projects for potential hydropower development. After further screening, 9 dam projects were shortlisted. These 9 dams will be implemented in different periods of time, stretching from 2013 to 2035. The economic hydropower potential of these dams is estimated to 1300 MW. Ethiopia is planning to export hydropower to its neighboring countries to earn desperately needed foreign currency [32]. The plans include also water supply schemes. Table 4 shows some of the immediate projects proposed to be implemented during the period between 2009 and 2020 .

The Ethiopian planned water-based development projects of the rivers will cost over 4 billion US\$ $[21,32]$.

\subsubsection{Kenya}

In Kenya, there are interests in river and groundwater development for irrigation and domestic uses, particularly along the Dawa tributary and the Merti aquifer [27, 33]. Kenya would like to increase its utilization of the Dawa river but is limited by the lack of security in the area and is concerned over the Ethiopian plans in upstream areas, which may then fail Kenyan projects [27]. Another obstacle is that the triangle area between Ethiopia-Kenya-Somali is a very problematic area of local conflicts, misunderstanding and social crisis and uncontrolled migration.

Kenya would also like to utilize the groundwater resources in the Merti aquifer, which currently provide water supplies for rural communities and the Dadaab refugee camp in north eastern Kenya with the world's largest refugees predominantly from Somalia. As the Merti aquifer is a non-renewable groundwater resources and prospects of development of the groundwater resources is potentially very high [34], a long-term transboundray management plan for its use needs to be jointly developed and agreed by both Kenya and Somalia.

\subsubsection{Somalia}

Before the civil war started in 1991, plans were in hand to further increase utilisation of the water resources in the two rivers. As the capacity to expand irrigation schemes remained high, development of over 250000 ha of controlled irrigation were proposed already in 1979 [35].

In the Shabelle basin, irrigation schemes totaling 88282 ha were planned. The proposed irrigation development demanded $1175 \mathrm{Mm}^{3}$ of water available in the river $[28,35]$. This was based on no-irrigation developments in Ethiopia. Table 5 shows proposed irrigation schemes in the Shallebe River.

In the Juba river basin, Somalia had in 1989 completed a master plan for the Juba Valley Development [36], which in turn produced the country's largest ever-planned development project, the Baardheere Dam Project (BDP). The $75 \mathrm{~m}$ high multipurpose dam was to regulate the entire flow of the Juba River. The proposed dam was located in 35 $\mathrm{km}$ upstream of Baardheere town in Somalia, a site identified in 1924. Regarded as a vital step towards food self-sufficiency and energy production, which received priority in development planning of Somalia, the multipurpose dam with its $5700 \mathrm{Mm}^{3}$ reservoir would irrigate 120000 ha, produce $140 \mathrm{MW}$ hydroelectric power and mitigate floods [36]. The BDP, which had the capacity to inundate the entire annual river runoff, was economically and technically motivated but politically failed [37]. The BDP did not materialize for many reasons.

Table 5. Proposed irrigation schemes in the Shabelle River in Somalia.

\begin{tabular}{|c|c|c|}
\hline Irrigation Project & $\begin{array}{c}\text { Irrigation } \\
\text { Area (ha) }\end{array}$ & Location \\
\hline Jowhar Irrigation scheme & 2600 & Jowhar \\
\hline Balcad Irrigation scheme & 16200 & Balcad \\
\hline Afgoi Irrigation scheme & 2500 & Afgoi \\
\hline Janaale Irrigation scheme & 4000 & Janaale \\
\hline Kurtunwaarey Irrigation scheme & 29742 & Kurtunwaarey \\
\hline Sablaale Irrigation scheme & 28740 & Sablaale \\
\hline Haaway Irrigation scheme & 4500 & Baraawe \\
\hline Total & 88282 & Shabelle basin \\
\hline
\end{tabular}

Somalia's proposed irrigation developments in the Juba basin demanded $4654 \mathrm{Mm}^{3}$ of water while $75 \%$ of the natural stream flow provides $3935 \mathrm{Mm}^{3}$ [35]. It is evident that there will be large deficient of water supplies from the river matched with the previous and proposed demands. Table 6 shows proposed water projects on the Juba River.

Table 6. Proposed water projects on the Juba River in Somalia before the civil war in 1991.

\begin{tabular}{|c|c|}
\hline Project & Details \\
\hline $\begin{array}{c}\text { Baardheere Dam } \\
\text { Project (BDP) }\end{array}$ & $\begin{array}{c}75 \mathrm{~m} \text { high dam with storage capacity of } \\
5700 \mathrm{Mm}^{3} \text {. Hydropower 140 MW. }\end{array}$ \\
\hline Irrigation schemes & $\begin{array}{c}120000 \text { ha irrigated land in downstream } \\
\text { areas of the Juba. }\end{array}$ \\
\hline Homboy irrigation & 4500 ha. \\
\hline
\end{tabular}

Source: $[29,36]$

\section{Analysis of transboundary water issues of the Juba and Shabelle river basins}

\subsection{Historical conflict and current tension between riparian states}

The relations between Ethiopia and Somalia is complex particularly in view of their long history of animosity, mistrust, conflict and border dispute, which resulted from the 
demarcations by the European Colonialists during $19^{\text {th }}$ and $20^{\text {th }}$ centuries. During that period, Ethiopia played a key role in the colonial division of the Somali Plateau into five areas $[38,39,40]$. As a result of colonial border demarcations, large population and communities of ethnically Somali origin live in Ethiopia and Kenya. The Ethiopian-Somali conflict and tension has a historical background in territorial and political disputes. These tense relations have resulted in political conflict, which led to two military wars in 1964 and 1977 and numerous military clashes along the borders during 1980s. Relation between Somalia and Kenya was also uneasy since independence in 1960. The idea of 'Greater Somalia', which was to unite all Somali population under one country, scared both Ethiopia and Kenya. In response to what both countries perceived as a continuing threat from Somalia; Ethiopia and Kenya concluded a mutual defense pact in December 1963 [41] immediately after Kenya's independence. The pact was renewed several times calling for the coordination of the armed forces of both states in the event of an attack by Somalia. Several leaders in the region have now disclosed $[42,43,44]$ and others revealed $[45,46]$ that Ethiopia and Kenya do not want to see Somalia standing on its feet again for one major reason - a powerful and stable Somalia will claim territories in Ethiopia and Kenya.

However, according to Ethiopia's policy towards Somalia [47], Ethiopia's vulnerability to the "Greater Somalia" ideology has been greatly diminished, as a result of Somalia becoming stateless. Since Somalia's state collapse in 1991, Ethiopia has several times been accused of supplying weapons to Somalia's functional leaders $[48,49]$ with the aim of destabilising the country [50]. Ethiopian troops occupied and invaded Somalia in 2006 and are inside Somalia since then for political reasons. Kenya army troops also entered into Somalia in 2011 and are there since then for political and security reasons. Although, Kenya is part of African troops to combat with terrorist groups, it was however several times accused having other hidden political and economic agendas in Somalia. In the Somali civil war, Ethiopia and Kenya have dominated the country's political processes and security issues, many times worsening the situation.

\subsection{Physical and political aspects of the rivers}

Ethiopia dominates the river basins in terms of basin area, river runoff as well as geographic position and population. Somalia is however the major water user in the basins and has a long history of irrigated agriculture on the plains of the rivers' banks. Despite living in different countries, the majority of the river basins' population are ethnically Somalis, although they do not occupy areas with the highest rainfalls of the two basins.

Despite being the largest basin of Ethiopia's twelve basins, covering one-fifth of country's territory, the Shabelle has the least runoff of all rivers. This meagre resource is a major source of water for Somalia and one of the limiting factors for its development. The Juba is the third largest basin in Ethiopia with less runoff compared to other basins in Ethiopia, but in Somalia it is the largest river in terms of river runoff. Somalia is located in a most disadvantaged position. Dividing the entire basins in three, Table 7 shows land share of basins' area by the countries.

Table 7. Land share of the river basins by riparian $\left(\mathrm{km}^{2}\right)$.

\begin{tabular}{|c|c|c|c|c|}
\hline River basin & Ethiopia & Kenya & Somalia & Total \\
\hline Shabelle & 188700 & 0 & 108300 & 297000 \\
\hline Juba-Genale & 143650 & 11000 & 66300 & 221000 \\
\hline Laag Dheera & 17000 & 180000 & 34000 & 231000 \\
\hline Total, area & 349350 & 191000 & 208600 & 749000 \\
\hline Total \% & $46 \%$ & $26 \%$ & $28 \%$ & $100 \%$ \\
\hline
\end{tabular}

Kenya is part of the basin but there are no observed surface runoff contributions from the Laag Dheere basin into the Juba River, and has no access to the main river thus any significant interests.

The two river basins cover geographically one-third of each riparian country's total land area. The basin areas in Ethiopia and Kenya are the least developed areas of these countries. However, the basins occupy Somalia's most populated and most important economic areas where strong future economic developments are needed to take place. Being currently the major user of the two rivers' water resources, Somalia has plans to further increase the utilization of the water resources in the rivers.

In the basins particularly in downstream reaches, there is available land suitable for irrigation. One of the main problems facing the river basins has its roots in limited availability of the water resources, in relation to existing and increasing demands. The level of economic and social development in the two basins is extremely low, as they largely depend on subsistence agriculture with low level of productivity. Due to lack of security in the river basins in the three countries, collection of data and information are limited and sometimes impossible to undertake any work.

\subsection{Importance of the rivers in Somalia's economy and ecosystems}

The Juba and Shabelle Rivers are important resource bases for Somalia, as they supply the country's rice bowl. Traditional socio-economic activities in southern Somalia are strongly based on the availability of water in the two rivers. Water resources in the two rivers are strongly linked to the very survival of the Somali national economy as well as its social and environmental well-being in the riverine areas. The rivers are vital to the well-being of the nation [35]. Unlike Ethiopia, which has larger rivers in its territories, Somalia lacks significant alternatives to the Juba and Shabelle rivers as long as water development for agricultural 
productions is concerned. The rivers pass through ecologically sensitive areas of both inland and coastal ecosystems. The dependency ratio of Somalia to the waters of the Juba and Shabelle are extremely very high. In Somalia, where agriculture is impossible without irrigation, water security is one of the most important issues.

In view of Somalia's economic dependence on the rivers, Ethiopia has in 1956 long before the Somalia's independence stated that the economy of the upcoming Somali state would not be viable standing alone, as it is strongly linked with Ethiopia [39]. This statement in mind, the Ethiopian master plans of the river basins with their large scale irrigation schemes and large dams reveals that the Somalia economy is in vulnerable state.

\subsection{River development projects in Ethiopia}

Ethiopia has not yet been using the water resources of the rivers. The Ethiopian master plans of the Wabi Shabelle and Genale-Dawa river basins reveal that the proposed major increase of water use for agricultural and energy productions in Ethiopia demand large scale mobilisation of the available water resources in the rivers. The proposed large dams and irrigation schemes have the capacities to utilise all available water resources in the two rivers, leaving no water for existing and future downstream uses in Somalia. Taking advantage of its hydro-hegemony, the Ethiopia's hydro-strategy makes sharing water more difficult. The dams produce not only hydroelectricity but also reliable, year-round water storages, which the country can divert for irrigation.

The Ethiopian hydropower development plans on the rivers create opportunities to earn foreign currency by selling hydropower energy to neighbouring countries, particularly to Kenya. Obtaining up to $400 \mathrm{MW}$ annually, Kenya has welcomed the power purchase agreement with Ethiopia [51]. Somalia may benefit from the idea of purchasing hydropower energy generated from the Genale River to Kenya, because this will create a condition where Ethiopia is required to release the water from the dams for power production, as this will in turn regulate the river flow for downstream uses in Somalia. In that case it is in the interest of Somalia. But if the water released from the dams are used for irrigation scheme in the lower reaches of the Genale River in Ethiopia, Somalia will then be affected negatively. In that case, Kenya is benefiting from the Genale system, in which they are not part of. Somalia is then neither getting the hydropower nor water for its existing and future irrigation needs.

From a transboundray perspective, these proposed dams have another advantage for Ethiopia. The main purpose is regulating the river flows for hydropower generation, downstream irrigation and flood control. This increases not only the water utilisation of the rivers in Ethiopia but it will also strengthen the country's position in the basins for future negotiation over the sharing of its benefits. Concerning Ethiopia's proposed water projects, Somalia has not been notified [52] and Ethiopia argues that there is no Somali government to notify and cooperate with [24]. In contrary to that argument, Ethiopian troops went into Somalia in 2006 with an agreement with the then transitional government. Notification is seen in Ethiopia as an obstacle to proceed with planned developments. As unilateral water developments have usually been predominant before negotiations [32], it is certain that Ethiopia decided with the idea of "build before any talks".

Most scenarios for water use and allocation modelling by Ethiopia shows large scale irrigation schemes [24b] with significant impacts on existing and planned downstream uses in Somalia. As a result of these large scale proposed irrigation plans in Ethiopia, Somali will be entirely transformed into rain-fed agriculture [53] and the Somalia government is very much concerned about the Ethiopian plans. In contrary to that, Ethiopia feels that it is being a hostage of Somalia's lack of central and functional government [54]. The two countries are in a position negatively affecting each other's desperately needed development of the two rivers' water resources. As long as Somalia is in a deep political crisis with no central and effective government, it will be difficult to argue with Ethiopia about their planned water development projects on the rivers.

\subsection{Ethiopian policies, water projects and effects on downstream Somalia}

Ethiopia has, after the overthrown of the military regime in 1991, gone into a new process of planning its internally available water resources, and adopting two policies that will have great impacts on its shared rivers including the Juba and Shabelle rivers. These are food self-sufficiency and energy production based on hydropower development.

Agricultural Development and Led Industrialization (ADLI) is a long term strategy to achieve faster economic development [32]. ADLI recognizes the urgent need for increased agricultural production. Food self-sufficiency policy demands total increase of utilization of internally available water resources for food production through establishing new large irrigation schemes, which will impact river flows for downstream uses.

The country has also decided to base all its energy production on hydropower, requiring large dam buildings on Ethiopia's major rivers. These dam developments will adversely impact on downstream uses in Somalia. Since irrigation is a major consumptive user of water, the Ethiopian irrigation plans in the very dry areas in the middle reaches of the river basins will demand large amount of water. This cause not only significant reduction of water flow to Somalia but also dries up the entire river flows.

The effect of these policies will be that they will increase the fears that Somalia has in these shared rivers, as Ethiopia can theoretically divert and control the water resources in the Jubba and Shabelle rivers. Diversion of river water for major consumptive uses such as irrigation in upstream areas of the 
basins will cause two major adverse impacts on Somalia:

1. Economic effect: reduction of water flows in the rivers will cause a collapse of existing irrigation schemes and planned irrigation developments.

2. Ecological effect: the entire rivers' ecology, particularly wetland areas in the Shabelle depression areas and the Juba estuary at the mouth of the river causing seawater intrusions. Planned irrigation and industrial developments in upstream will cause negative effects on the water quality in downstream areas of the rivers.

These major adverse impacts on the rivers' downstream uses in Somalia will be pronounced in low flow periods. The rivers are already experiencing flow reduction due to the basins' high evaporation, seepage and over bank spillages [55]. In addition, as a result of the Ethiopia's proposed upstream developments, the Juba and Shabelle rivers will experience further four more major losses:

1. Consumptive uses for irrigation schemes.

2. Evaporation losses from the large reservoir areas.

3. Flow reduction during impoundment of reservoirs after the completion of the dams.

4. Changes in flow regime over time.

Considering large reservoir areas with an annual evaporation rates exceeding $1500 \mathrm{~mm}$, an irrigated areas of only 200000 hectares in upstream Ethiopia consuming large amount of water, and natural seepage and other losses, the flow of the Juba and Shabelle rivers in Somalia could be drastically reduced. In both river basins, Ethiopia warns that their planned schemes will affect Somalia mainly during low flow period.

Ecological claims on the water resources are more difficult to validate than those for other uses. They will however be affected by the reduction of rivers' water flows.

In terms of river flows, large dams for hydropower production in upstream areas will regulate the river flows. Somalia would necessarily be beneficial from any upstream river regulation for non-consumptive uses, which may increase dry period flows and decrease high flows during flood periods.

\subsection{Ethiopian arguments and international water principles}

In view of internationally accepted water principles, Ethiopia's arguments are mainly based on the principle of reasonable and equitable utilisation, while the country does not endorse the principle of not to cause significant harm [24]. This principle was perceived as an obstacle to its planned development favouring downstream uses. In the master plans of the two rivers, which analysed the effect of these principles on the planned developments, Ethiopia showed clear reluctance to the UN Convention on the laws of non-navigational uses of the international watercourses, and preferred to apply to the Helsinki Rules instead [32].

It is worth to note that in 1997 when the Convention was introduced to the UN member states, Ethiopia and Kenya were present at the meeting while Somalia was absent. Kenya voted in favor of the UN Convention while Ethiopia abstained. None of the countries has however signed or ratified the UN Convention. Ethiopia is very much worried about the "no-harm" principle [ibid.], arguing that the rule prevents them using the rivers, particularly when the rivers are extensively used by downstream Somalia.

Due to the absence of an international agreement on these shared rivers, Ethiopia argues that it has the sovereign right to proceed unilaterally with its development of water resources within its territory without considering effects on downstream uses in Somali.

\subsection{Somalia's Baardheere dam project on the Juba River and the Ethiopian objection}

In 1985, Somalia applied for funds from the World Bank for the implementation of the Baardheere dam project (BDP) on the Juba River. The Bank informed Somalia of the need to notify Ethiopia and Kenya of the project [56]. However, because of the strained relations between Somalia and Ethiopia at that time, Somalia asked the Bank to undertake the notification on its behalf. It indicates that Somalia was not willing to involve Ethiopia in its dam project plans. Ethiopia objected to the project in 1987 claiming that the dam would cause appreciable harm to their interests and they have the potential to impound all the discharges of the Juba River for irrigation and hydropower development [ibid.]. Although Ethiopia suggested negotiation with Somalia concerning the common use of the waters of the Juba River, Ethiopia objection was mainly based on the fear that the BDP would create a strong bargaining position for Somalia in the future. The dam would also establish a higher level of prior use of the Juba's water by Somalia that would later be claimed as acquired rights, in case water allocations were to be negotiated in the future. Ethiopia's response, in essence, indicated an understanding on the part of Ethiopia of the concept of foreclosure of its future uses [57] as a consequence of acquired rights to the finite water resources.

The Bank proposed that Somalia should hold negotiation with Ethiopia over the sharing of the Juba River or accept a third party involvement to facilitate a resolution of the sharing of the river [56]. Somalia was not amendable to these ideas. The reasons why Somalia did not want to negotiate with Ethiopia were many, but the major one was that the Juba River crosses over a disputed border area with Ethiopia. Negotiating with Ethiopia over the Juba would recognize the existing border and this would give Ethiopia an unprecedented opportunity to put an end to the issue of the Ogaden area, which Somalia was claiming since its independence.

According to the Ethiopian master plan, the proposed large dams on the Genale-Dawa river will obviate the BDP [32b] and this will be impossible from Somalia [53].

\subsection{Complementarities of region's resources and incompatibility of the development policies and}




\section{plans}

Prospects for hydropower development in upstream areas and irrigation development in downstream areas of the basins are significant. In addition, Ethiopia is in desperate need in access to the sea while Somalia has plenty of ports which can supply Ethiopia. Somalia's economy is dependent on reliable access to the river waters. With its unexploited natural and economic resources, complementarity of the region's resources is very high.

Agriculture is by far the most important socio-economic activity sector in the basins. Development of the agricultural sector is therefore of high importance to the economy of the three riparian countries of the Juba and Shabelle basins.

In Ethiopia, the agricultural sector accounts for 45 per cent of GDP, 90 per cent of exports and 85 per cent of employment. Since the agriculture sector greatly influences economic performance in the country, Ethiopia sees agriculture sector as the engine of growth [57]. Ethiopia's Policy and Investment Framework (PIF) provides a strategic framework for the prioritization and planning of investments which in turn will drive Ethiopia's agricultural growth and development. Since 1991, the Ethiopian government has been implementing its strategy of Agricultural Development Led Industrialization (ADLI), which is a central pillar of its economic policy [58]. In the agricultural sector, Ethiopia has a comprehensive and consistent set of policies and strategies, which reflects the importance of the sector in the Nation's development aspirations. Ethiopia's Agriculture Sector Policy and Investment Framework (PIF) are planning to invest USD 16.6 billion in the sector.

In Somalia, irrigation as a way to increase the agricultural production, is a key factor to the country's food security and economic development [29]. As agricultural sector development was importance to Somalia, the country has during the 1970s adopted a national policy of food self-sufficiency. Before the civil war in 1991, the total irrigated land was 222950 ha [59] and more irrigation schemes for further increase of agricultural production were planned to implement.

Ethiopia and Somalia have also similar plans of generating hydropower from the same river, i.e. the Juba where Somalia in 1980s wanted to implement the BDP for hydropower development. Ethiopia proposed as well to develop the Genale - the Juba's upstream tributary - for a large scale hydropower generation.

The challenges facing Ethiopia and Somalia are remarkably similar, as both countries give high priorities to irrigation development in their national development plans as a way to increase agricultural and food production. It seems therefore incompatible to reconcile their competing and conflicting needs. Both countries developed major plans for multipurpose dam projects for irrigation and hydropower, demanding more supplies from the rivers.

In the Shabelle basin, existing and planned irrigation in Somalia have the capacity to absorb all the readily available water resources in the river, and any small increase in consumptive use of the river water in Ethiopia would greatly affect both present and future irrigation schemes in Somalia. In volumetric terms, Ethiopia plans to utilize $2566 \mathrm{Mm}^{3}$ of water mainly for irrigation while Somalia wants to increase its water uses for irrigation to $1175 \mathrm{Mm}^{3}$. The natural river flow does not provide the sum of the two proposed amounts.

In the Juba river basin, Somalia demands $4654 \mathrm{Mm}^{3}$ of water while $90 \%$ of the natural stream flow provides 3935 $\mathrm{Mm}^{3}$ [35] while Ethiopia proposed to make a tremendous increase in their consumptive water utilization in upstream areas. Ethiopia is determined to dam the rivers for irrigation purposes [47]. Somalia [35] estimated in 1978 that Ethiopian water demands from the rivers in the future would be 2400 $\mathrm{Mm}^{3}$. Considering the existing water uses and proposed demands and taking into account the limited amount of the rivers' water resources, the sum of all demands are likely to exceed available supplies.

\subsection{Kenyan proposal for cooperation over common water systems}

By sending several letters to Ethiopia, Kenya initiated a dialogue with Ethiopia aimed for establishing cooperation over the common rivers $[27,33]$. In the letters, Kenya has proposed a cooperative framework agreement to establish a joint Lake Turkana and rivers Omo and Dawa basin commission. Ethiopia responded very slowly and with no commitments [ibid.]. Ethiopia argued that they will consider the proposal after studying the rivers [34], which they have already completed in 1996 for the Omo and 2007 for the Dawa. In the eyes of Kenya, Ethiopia seems to be very much reluctant to river cooperation. Kenya is also willing to approach Somalia for cooperation over the shared water systems. Despite its tense relation with Somalia and the presence of its troops in that part of the basin in Somalia, Kenya could be instrumental for future cooperation over the Juba River.

\subsection{Growing water scarcity and looming water conflict}

Joining water scarce countries in the world, all three countries in the Juba and Shabelle basins have passed the point defined to indicate severe water stress and water deficit [60], and where water scarcity effectively limits further development. Under these water scarcity conditions, high level of technology and large-scale irrigation schemes will be necessary in order to increase the food production. Due to their climate combined with population growth, the countries experience both natural and demographic water scarcities. As shown in Figure 2, the flow of the two rivers in the period between December and April is extremely low, fundamentally limiting any possibility of irrigation. The uncertainty about the timing and magnitude of the river flows has great socio-economic and ecological consequences. Being Ethiopia's most water scarce basins and with the greatest food insecurity, the Genale-Dawa and Wabi Shabelle have the country's lowest level of economic and 
social development [21, 24].

The amount of water that Ethiopia has planned to divert to irrigation development, in the case of the Shabelle, is much more than what is available at the border with Somalia. Somalia has long before also expressed their need and capacity to absorb all readily useable water resources for existing and future irrigation schemes in the Shabelle [35]. According to Ethiopia master plans, large amount of water will be utilized for irrigation. Ethiopia has explicitly stated that the demand will become competitive and conflict will begin to rise [24]. With its upstream geographical position, Ethiopia makes clear for Somalia that they will divert the water on a first-come first-served basis [ibid, 24b]. Within prior appropriation principle, Somalia may claim priority over Ethiopia by arguing first-in-time first-in-right. These strongly conflicting principles on the same river systems can lead the riparian countries to a new water crisis in an already water-scarce region.

Being in a deep concern over the sensitivity of the river systems to Ethiopian irrigation developments, as any small increase in consumptive use of the rivers' water in Ethiopia will compromise not only Somalia's future uses but also their existing irrigation schemes, it is certain that there is a looming water conflict between the riparian states.

Despite of these growing water scarcities and looming water conflict over the shared rivers, and despite the conditions experienced by the Juba and Shabelle rivers that fulfills all criteria for potential water conflict, active interstate conflict in the Horn of Africa based on the Juba and Shabelle rivers remains very low for many reasons. Ethiopian military superiority in the region, its upstream geographic position of the rivers, relatively economic powers and its diplomatic clout in the international systems are some reasons. Somalia, being the neediest and the most downstream riparian with no institutional capacities and central system of government for the last twenty two years to restore its established water uses and to undertake major proposed water projects in the near future, is in a collapsed-state position and in a deep sociopolitical crisis. In addition, the upstream riparians, Ethiopia and Kenya, are deeply involved in the Somalia's political and security affairs.

\section{Required river cooperation and its obstacles}

\subsection{Driving forces for cooperation over the river basins}

It is evident that the riparian states of the Juba and Shabelle are inherently inclined to exploit the water resources in the two rivers unilaterally and do not have an interest in cooperation. Cooperating over their shared water resources is now not an option; it is necessary for any future development of their common water resources.

As in many other regions [14], the most driving factors for river cooperation is the basins' water scarcity. The basins' population growth combined with increasing water scarcity and food insecurity could also be seen as main reasons for seeking the desperately required cooperation over the rivers. In addition, as a result of the region's growing economy, the water resources of the two rivers have now got more economic value than before. As the link between scarcity and conflict is already confirmed [61], a dispute over the Juba and Shabelle rivers can be a potential source of conflict. Initiating cooperation over the rivers is again necessary not only for preventing the looming crisis and the risk for water conflict but also benefiting its potential resources. In order to avoid a 'tragedy of commons' [ibid.] or unilateral abuse and overutilization of the rivers' scarce water resources, common forms of resource management are absolutely necessary.

\subsection{Obstacles for desperately needed river cooperation}

Issues that prevent negotiations and establishing cooperation for benefit sharing through common management are many. During the period between 1960 and1990, Somalia developed the two rivers as its own national rivers within its national territory. In its river basins' master plans, Ethiopia has similarly planned to develop the entire waters of the two rivers as they are national ones. These unilateral actions for river developments imply and reflect policies of no-will-for-cooperation. Unilateralism is therefore the major obstacle to the desperately required cooperation over the rivers. Ethiopia, being the strongest nation in the basins, faces the greatest water scarcity because of their relatively large population and growing economy. This with its upstream position paves the way for Ethiopia to undertake any water projects as it planned on unilateral basis avoiding any attempt for negotiation and cooperation.

Other major obstacles include severity of the water scarcity in the riparian countries and in the river basins, geographical balance of the problem, the riparian countries' historical conflicts and current tensions, growing population, and the border disputes.

In addition, the lack of central and functional system of government in Somalia for the last twenty two years seems to be the most major hinder. The Somalia's statelessness which led to lack of effective downstream riparian has created a condition of imbalance within the riparian states. This is a unique case of all international river basins. Opportunities for required negotiation and joint planning of the Juba and Shabelle rivers are also constrained by the considerable capacity imbalances among the countries.

\section{Benefit sharing through river cooperation/regional economic integration}

\subsection{Potential opportunities for common development and benefit-sharing}


Since the two rivers lack currently major water infrastructures, there are potential opportunities for making better planning for sustainable development of water utilisation. Identifying development strategies and incentives for cooperation, the riparian countries need to come up with common approaches evaluating sharing of the benefits from river cooperation. From engineering and economic development of the resources point of view, water should be developed where it can give the highest economic value in that particular geographic area. The best approach for making this evaluation is river basin approach which is the best planning and management unit. It is evident that the upper reaches of the two rivers are suitable for hydropower development while the downstream areas suit for irrigation developments. As water has multiple uses and links many sectors, joint river planning creates opportunities for integrating several economic sectors such as water, agriculture, livestock and energy.

In addition, regulating the rivers in upstream areas in Ethiopia for non-consumptive uses will reduce the risk for devastative flooding in downstream Somalia and increase the dry period flows, and this would necessarily be beneficial to downstream uses in Somalia.

\subsection{Regional economic integration - the optimal solution}

One opportunity that could be explored but demands political commitments is to go into a regional economic integration based on water [16]. The rivers could play significant roles in this integration. In order to facilitate negotiation process for river cooperation it seems useful and necessary to include other economic issues than water in the discussion.

Being the world's largest landlocked nation, Ethiopia is in a desperate situation regarding its lack of a reliable outlet access to the sea for the survival of their economy. Sovereign states do not like to share with other states what it considers to be its own resources [3]. Although ports on the Somalia's coastline are the country's own natural resources, Somalia has to share them with its landlocked neighboring country.

In view of this, the existing opportunity, which the two countries, Ethiopia and Somalia could mutually benefit, is to allow the two rivers to run into Somalia without major consumptive uses in upstream Ethiopia in exchange to freely accessible ports for Ethiopia in the Somalia's long coastal lines. This economic integration strongly demands commitments that should be made by the two countries assuring a joint security and save co-existence in the future.

\section{Conclusions}

The Juba and Shabelle rivers are in an underdeveloped, water-scarce and conflict ravaged region of the Horn of Africa. The river basins are shared by Ethiopia, Kenya and Somalia. The rivers are lacking agreement between its riparian states over its utilizations. In both river basins,
Ethiopia dominates in many decisive terms such as land area, river runoff, population and political power.

Being the major user of the resources, Somalia is the most downstream state. Somalia is in the most disadvantaged position in geographical, hydrological, political and economic terms. Ethiopia is implementing large scale water projects for hydropower and irrigation development on the rivers. These large dams and irrigation canals are negatively affecting Somalia's water security mainly for its existing and planned irrigation schemes both in economic and ecological terms. Somali was not notified and informed about the Ethiopian planned water development projects in the rivers.

Cooperation between the basin states is not an option but absolutely necessary for conflict prevention and optimal utilization of the rivers' water resources. The river basins are however experiencing several major obstacles for any attempt to initiate the desperately required cooperation. These include the basin states' unilateral action plans for the development of the rivers, the lack of functional government in Somalia since 1991, the historical conflict with border dispute and current tensions. Unwillingness to negotiate and notify, and objecting proposed dam projects indicate that the basin states of the rivers are not considering cooperation as a way to develop common water resources. With its many unresolved disputes and conflicts between the basin countries, the issue of the Juba and Shabelle rivers is a complex one.

As cooperation becomes possible only when it serves the interest of more powerful riparian state [63], which in this case is also upstream riparian contributing almost all the rivers' runoffs, cooperation that is not giving Ethiopia most benefits seems to be impossible. The interest of Ethiopia is therefore prerequisite for any cooperation.

From the case study, it is certain that water management of any of the basin states is one of transboundary requiring cooperation, in order to reduce the risk for conflict and contribute to the development of the resources. For this reason, development on the upper parts of the Juba and Shabelle river basins cannot be made without considering effects further downstream.

Apart from the river basins' physical water scarcity due to the low rainfall and higher evaporation, population growth, intensified economic development and pollution increase cause further water scarcity. As a result, the rivers' waters are increasingly getting more economic value than before. In this regard, it appears that the water should then be developed where it could give highest economic return. Using the river basin as a planning unit, and integrating the sectoral water uses, the upper reaches of the two rivers are suitable for hydropower developments while the downstream areas suit for irrigation developments. Joint planning of the river basins can therefore give optimal utilization of its water resources for the benefit of its basin countries and communities.

The issue of water development and sharing is as much if not more of a policy issue as it is a physical issue. To resolve the issue of the Juba and Shabelle rivers and address the 
required cooperation in the basins, two combined approaches can be adopted: (a) an integrated management of water resources; that will reconcile and optimize the variety of possible uses of water in the basins; (b) a basin-system cooperation that brings riparian states on the negotiation table for joint planning and management.

The Juba and Shabelle rivers are the economic bases that could drive both conflict and cooperation. If the former is to be avoided, determined moves are needed towards regional economic integration. Moreover, the potential benefits of cooperative management of the shared rivers can serve as catalysts for broader regional cooperation, economic integration and even conflict prevention.

Although regional economic integration appears to be a political impossibility at the moment, it may also be proved to be an unavoidable reality as the shared rivers could be regarded as one of the drivers of economic integration. Bringing other issues than water into the discussions could facilitate a future negotiation process for basin cooperation. Exchanging freely accessible ports for Ethiopia along the Somali long coastlines with undisturbed but regulated river flows to Somalia for irrigation uses could be possible through regional economic integration.

\section{REFERENCES}

[1] Delli Priscoli, 1998. Water and civilization: Conflict, cooperation and the roots a new eco-realism. Stockholm, Sweden. $17 \mathrm{pp}$.

[2] Biswas, Asit, K., (ed.) 1996. Water Resources Management: Environmental Planning, Management, and Development. McGraw-Hill. p.18

[3] Elhance, Arun, 1999, 'Hydropolitics in the Third World: Conflict and Cooperation in International River Basin'. United States Institute of Peace, Washington, D.C. p. 13, 233, 236.

[4] Philips, D.J.H., M. Daoudy, J. Öjendal. A. Turton and S. McCaffrey, 2006. Trans-boundary Water Cooperation as a Tool for Conflict Prevention and for Broader Benefit-sharing. Ministry of Foreign Affairs, Stockholm, Sweden. pp.15.

[5] World Bank, 1998. International Watercourses: Enhancing Cooperation and Managing Conflict. Salman M. A. Salman and Laurence Boisson de Chazournes.

[6] Kitissou, M., Ndulo, M., Nagel, M., and Grieco, M., 2007. The Hydropolitics of Africa. A contemporary challenge. Cambridge Scholars PubliShing. Page 1.

[7] Ashton, J., Peter, 2002. Avoiding Conflicts over Africa's Water Resources. AMBIO, volume 31, no 3, pp236-242.

[8] Ashton, J., Peter, 2008. Disputes and conflicts over water in Africa. In: Mlambo, Norman (ed.), 2008. Violent Conflicts, Fragile Peace: Perspectives on Africa's Security. Adonis \& Abbey Publishers Ltd, London.

[9] Gleick, Peter, H., 1999. The Human Right to Water. Water Policy. Vol. 1, pp.487-503.
[10] Swain, A., 2004. Managing water conflict. Asia, Africa and the Middle East. p.33.

[11] Wolf Aaron, T., Natharius, J. A., Danielson, J., J., Ward, B., S., Pender, J., 1999. International River Basins of the World. International Journal of Water Resources Development, Vol. 15, No. 4 .

[12] Falkenmark, Malin, 1989. The Massive Water Scarcity now Threatening Africa: Why isn't it Being Addressed? In Ambio, Vol. 18, No. 2; 112-118.

[13] Tafesse Tesfaye. The Nile Question. Hydropolitics, Legal Wrangling, Modus Vivendi and Perspectives (Munster: Lit Verlag, 2001). See p.6 file: Hydropolitics and Geopolitics.

[14] Granit, Jakob, 2012. The Collective Action Dilemma in Managing Transboundary Freshwaters: An Analysis of an Outcome-Driven Framework. Dissertations from the Department of Physical Geography and Quaternary Geology, Stockholm University.

[15] Hinrichsen, D. and Tacio H., The coming freshwater crisis is already here, in Finding the Source: The linkage between population and water (Washington DC: Woodrow Wilson International Centre for Scholras, ECSP Publication, 2002)

[16] Elmi, M., Abdullahi, and Iman, M., Hussien, 2010. Hydropolitics in the Horn of Africa - Conflict and required cooperation in the Jubba and Shabelle Rivers. In: Shared waters, shared opportunities: Hydropolitics in East Africa (eds.) Bernard Calas \& C. A. Mumma Martinon. Nairobi, Kenya. p.37-52.

[17] Stake, R. E., 1995. The art of the case study research. Thousand Oaks, CA: Stage.

[18] Yin, Robert K. 1994. Case Study Research. Design and Methods Second edition. Thousand Oaks, Stage.

[19] Bryman, Alan, 2012. Social research methods. Oxford University Press. 4th Edition. P709

[20] FAO-SWALIM, 2010. Atlas of the Juba and Shabelle Rivers in Somalia. Nairobi, Kenya. p.2, 3.

[21] Ministry of water resources, Ethiopia, 2004. Wabi Shebele river basin integrated development master plan study project. Volume I Main report. p.122, 134.

[22] FAO. 1989. A Brief Description Major Drainage Basins Affecting Somalia. Prepared by D. Kammer. National Water Centre, Mogadishu. Project Field Document No. 14. SOM/85/008.

[23] Mwango, Fred K., B.C. Muhangú, C.O. Juma, I. T. Githae, 2002. Groundwater resources in Kenya. Laboratoire des Sciences et Techniques de l'Eau et de l'Environnement. Université de Cocody. Proceeding of the International Workshop. Tripoli, Libya. 2-4 June, 2002.

[24] Ministry of water resources, Ethiopia, 2007. Genale-Dawa river basin integrated resource development master plan study. Lahmeyer International / Yeshi-Ber Consult. Final Report Volume II.1 Hydrology and Climate. p. 64, 24, 171, 173.

[24] Ministry of water resources, Ethiopia, 2007. Genale-Dawa river basin integrated resource development master plan study. Lahmeyer International / Yeshi-Ber Consult. Final Report Part I.1 Master Planning Models. p. 16, 20. 
[25] Ministry of Juba Valley Development, Somalia, 1990. Master plan for Juba Valley Development. Annex 1 Water. GTZ. Agrar Und Hydrotechnik GMHB. Pages 33, 50

[26] Gebeyehu, Admasu, 2004. The role of large water reservoirs. Second International Conference on the Ethiopian Economy. The Ethiopian Economic Association. June 3 - 5, 2004. United Nations Conference Center (UNCC). Addis Ababa, Ethiopia. Page 17.

[27] Mugera, Eunice, 2011. Personal communication. Ms Eunice Mugera is a Hydrologist at the Department of Transboundry Waters, Ministry of Water \& Irrigation, Nairobi, Kenya. I met with Ms Eunice in her office at the Ministry on the 16th, November 2011.

[28] SWALIM, 2010. Somali water and land resources - Calling for attention. Funded by EU and UNICEF. Implemented by FAO. Nairobi. Pages $57-67$.

[29] Mbara C.J., Gadain H. M and Muthusi F.M., 2007. Status of Medium to Large Irrigation Schemes in Southern Somalia, Technical Report No W-05, FAO-SWALIM, Nairobi.

[30] Basnyat, D. B. and Gadain H. M., 2009: Hydraulic Behaviour of the Juba and Shabelle Rivers: Basic Analysis for Irrigation and Flood Management Purposes. Technical Report No W-13, FAO-SWALIM, Nairobi, Kenya.

[31] Ministry of water resources, Ethiopia, 2004. Wabi Shebele river basin integrated development master plan study project. . Final report. Section II Sectoral Studies. Volume IX - Water Resources. Part 6 - Dams and Reservoirs. p. 25, $26,31,46,48$.

[32] Ministry of water resources, Ethiopia, 2007. Genale-Dawa river basin integrated resource development master plan study. Lahmeyer International / Yeshi-Ber Consult. Final Report. Volume I.1 Main Report. p20, 22, 325-6.

[32] Ministry of water resources, Ethiopia, 2007. Genale-Dawa river basin integrated resource development master plan study. Lahmeyer International / Yeshi-Ber Consult. Part II Sector Studies. Vol. II.3 H. Irrigation and Drainage. p40-43.

[32] Ministry of water resources, Ethiopia, 2007. Genale-Dawa river basin integrated resource development master plan study. Lahmeyer International / Yeshi-Ber Consult. Part II Sector Studies. Vol. II.3 G. Hydropower. p31.

[33] Mwango, Fred K., 2012. Personal communication. Mr Fred K. Mwango is the head of the Department of Transboundry Waters, Ministry of Water \& Irrigation, Kenya. I met him in Stockholm, Sweden during the World Water Week in 31st August, 2012.

[34] Mumma, A., Lane, M., E., Kairu, Tuinhof, A., and Hirji, R., 2011. Kenya Groundwater Governance Case Study. World Bank. Water Partnership Program. Water Papers.

[35] Somalia, Democratic Republic, 1979. Present and Future Irrigated Agriculture in the Shabelle and Juba River Basins. By Jean C. Henry, Consultant Hydrologist. FAO, Rome. p29, 30 ,

[36] Ministry of Juba Valley Development, Somalia, 1990. Master plan for Juba Valley Development. Main report. GTZ . Agrar Und Hydrotechnik GMHB. pages 36, 106, 129, 132-33, 199.

[37] Godah, Barre, Mohamed, 2000. Personal Communication. Mr.
Godah is a former Somali Minister for National Planning and Juba Valley Development. Lohja, Finland. 12th August.

[38] Lewis, I., M., 1980. A Modern History of Somalia - Nation and State in the Horn of Africa. Longman. Longman Group United Kingdom.

[39] Drysdale, John, 1964. The Somali Dispute. London, Pall Mall Pr. p.83.

[40] Tripodi, Paolo, 1999. The colonial legacy in Somalia: Rome and Mogadishu from colonial administration to Operation Restore Hope. Palgrave Macmillan.

[41] Hornsby, Charles, 2012. Kenya - A history since independence. I. B. Tauris. New York. p179.

[42] East African Standard, 2003. Moi guest speaker at American University. Former president of Kenya Mr Daniel Arab Mo said one of the drawbacks in the Somalia peace process was the regional suspicion that a united Somalia might pursue its "expansionist dreams". Speaking in American Defense University in Washington, Moi said some of the countries neighboring Somalia, feared that a re-united and prosperous Somalia might resurrect its early territorial claims. http://business.highbeam.com/3548/article-1G1-107945765/ moi-guest-speaker-american-university

[43] Yusuf, Ahmed, Abdullahi, 2012. Halgan iyo Hagardaamo taariikh Nololeed. Struggle and Conspiracy - A Memoir. Scansom. Stockholm.

[44] VOA, 2013. Interview with Mr Abdirisak Hagi Hussien, former Prime Minister of Somalia between 1964-1967. Minneapolis, Minnesota, USA.

[45] Plaut, Martin, 2012. How stable is the Horn of Africa? Paper for the Horn of African Conference in Lund, Sweden, 8-10 June, 2012. Lund, Sweden. Mr Plaut is Africa editor of the BBC World Service News.

[46] Samatar, A., I., 2009. Personal communication with Prof. Samatar of the Minnesota State University. Lund, Sweden.

[47] Ministry of Information, 2002. Foreign Affairs and National Security - Policy and Strategy. Press \& Audiovisual Department Addis Abeba. pp73-75. http://www.mfa.gov.et/docs/Foreign\%20Policy\%20English. pdf

[48] UN, 2003. Report of the Panel of Experts on Somalia pursuant to Security Council resolution 1425 (2002). Letter dated 25 March 2003 from the Chairman of the Security Council Committee established pursuant to resolution 751 (1992) concerning Somalia. United Nations, Security Council.

[49] Wezeman, Pieter, D., 2010. Arms flows and the conflict in Somalia. SIPRI Background Paper. http://books.sipri.org/files/misc/SIPRIBP1010b.pdf

[50]

http://en.wikipedia.org/wiki/Ethiopian\%E2\%80\%93Somali_ conflict

[51] Ministry of Foreign Affairs of Ethiopia, 2012. Prime Minister Meles' State Visit to Kenya. The statement was published in A Week in the Horn of Africa, a weekly press release of the Ethiopian Ministry of Foreign Affairs. Published date 9th of March 2012. The press release refers the official speeches of President Kibaki of Kenya and PM Zenawi of Ethiopia in 
Nairobi.

[52] Ghedi, Ali, Mohamed, 2011. Personal communication with $\mathrm{Mr}$ Ali Mohamed Ghedi, former Somali Prime Minister (2004-2007). I met him at Serena Hotel in Nairobi, 15th November, 2011.

[53] Mohamud, Mohamud, 2012. Personal communication with Mr Mohamud Mohamud, director-general of Ministry of National Resources, Somalia. 15th December, 2012. Mogadishu.

[54] Gebeyehu, Admasu, 2009. Personal communication with Dr Admasu Gebeyehu, a senior water professional. 9th August, 2009. Lund

[55] Basnyat, D. B., 2007. Water resources of Somalia. Technical report No W-11, FAO- SWALIM, Nairobi Kenya.

[56] Salman, M., Salman, 2011. The Baardhere Dam and Water Infrastructure Project in Somalia-Ethiopia's objection and the World Bank response. Hydrological. Sciences Journal 56(4), 630-640.

[57] Salman, M.A., Salman, 2010. Downstream riparians can also harm upstream riparians: the concept of foreclosure of future uses, Water International, 35:4, 350-364.

[58] Ministry of Agriculture and Rural Development, 2010. Ethiopia's Agricultural Sector Policy and Investment Framework (PIF) 2010-2020.

[59] FAO, 1977. Water use in irrigated agriculture. Democratic Republic of Somalia. A country brief. Messrs. J., Doorenbos and M., Smith, FAO Rome. p.1

[60] Falkenmark, Malin, 1989. The Massive Water Scarcity now Threatening Africa: Why isn't it Being Addressed? In Ambio, Vol. 18, No. 2; 112-118.

[61] Toset, H.P.W., Gleditsch, N.P. Hegrge, H. 2000. Shared river and interstate conflict. Political Geography 19: 971-996.

[62] Hardin, G, 1968. The tragedy of commons. Science 162: 1243-1248.

[63] Lowi, M., 1993. Water and Power: The Politics of a Scarce Resources in the Jordan River Basin. Cambridge: Cambridge University Press. 